International Journal of Library \& Information Science (IJLIS)

Volume 7, Issue 5, September-October 2018, pp. 27-35, Article ID: IJLIS_07_05_002

Available online at

http://iaeme.com/Home/issue/IJLIS?Volume=7\&Issue $=5$

Journal Impact Factor (2016): 8.2651 (Calculated by GISI) www.jifactor.com

ISSN Print: 2277-3533 and ISSN Online: 2277-3584

C) IAEME Publication

\title{
ACCESS TO CERA CONSORTIUM IN SKUAST-K, FISHERIES E-JOURNALS: AN INFORMATIVE STUDY
}

\author{
Asifa Jan \\ Assistant Librarian, SKUAST-K \\ Faculty of Fisheries, Rangil, Ganderbal, 190012 \\ Ridwana Bach \\ Asstt Librarian, SKUAST-K \\ FVSc \& AH, Shuhama
}

\begin{abstract}
The paper provides the brief background of the Indian Consortium for $e$ Resources in Agriculture (CeRA) and the components of the National Agricultural Innovation Project (NAIP) with special reference to the Component-I under the important and most innovative web-based projects, i.e., CeRA, The overview of these project including objectives and deliverables has been highlighted especially keeping in view of the current scenario of the MPKV. There are several library consortia in India, UGC Infonet is mainly meant for universities controlled by UGC and CeRA is meant for agricultural universities. The results reveal that CeRA e-Journal in Fisheries Science is inceasing at an exponential rate and currently 87 fisheries Journal are registered in CeRa. These Journals are published from 12 countries from 18 publishers in 07 languages. The maximum Journals are published from USA (81.61\%), by Elsevier publisher (29.87\%).
\end{abstract}

Key words: CeRA; E-Journals; Fisheries Science; SKUAST-Kashmir

Cite this Article: Asifa Jan and Ridwana Bach, Access to CeRA Consortium in SKUAST-K, Fisheries E-Journals: An Informative Study. International Journal of Library \& Information Science, 7(5), 2018, pp. 27-35.

http://iaeme.com/Home/issue/IJLIS?Volume=7\&Issue $=5$

\section{INTRODUCTION}

Timely access to information is becoming more and more crucial for survival in every sphere of life and agriculture sector is no exception. In the present competitive world, moving towards what we perceive as knowledge society, the access to right information at anytime, anywhere, about anything has gained high significance. This off course does not mean that the earlier societies were not aware of importance of information or were not knowledgeable. The 
information played very important role even in ancient time especially in field of agriculture. Today information has become absolutely important input in agriculture. Agricultural research, the backbone of agricultural growth in the country, demands timely dissemination of knowledge being generated and updated across the globe from time to time. R \& D institutions have been procuring print versions of journals and literature in aid of science and technology. With the rapid growth of internet facilities and advancement of web technology, almost all reputed international journals are available on-line and can easily be accessed by researchers over the network. Since ICAR is having network connectivity across institutes and state community. Accordingly, the National Agricultural Innovation Project (NAIP) has funded for establishing the Consortium for e-Resources in Agriculture (CeRA) at the Indian Agricultural Research Institute (IARI) in November 2007 to facilitate accessibility of scientific journals to all researchers/teachers in the National Agricultural Research System by providing access to information specially access to journals online which is crucial for having excellence in research. As the universities in India are broadly controlled by two agencies like UGC and ICAR, the library and information resources management and services are also performed differently. While the universities under UGC have formed UGC Infonet for consortia mode of journal subscription and electronic information services, the agricultural universities and agricultural research institutes formed CeRA for the same purpose. Moreover, there are several other consortia also in operation in India for institutions under CSIR, DRDO, IITs, IIMs, etc.

\subsection{Formation of consortium for e-resource in Agriculture}

CeRA was launched successfully on 30 April 2008.Access to CeRA was initially given to 124 institution though IP addresses, out of 124 institution,114 institution successfully received access though IP addresses, but institutes located in remote areas got access through user ,name \& password. It covers agri, vety sc, fisheries crop sc, computer sc, soil sc, animal science Currently 147 institutions in NARS have $24 \times 7$ online accesses to important journals in CeRA platform through IP authentication. Thomson Web of Science for Science Citation Index (SCI) has been made available to the Lead Institute (IARI), but the facility is available to all members of CeRA

\section{OBJECTIVES OF CERA}

a) To upscale the existing $R \& D$ information resource base of ICAR institutions/universities comparable to world's leading institutions/organisations;

b) To subscribe e-journals and create e-access culture among scientists/teachers in ICAR institutes/ agricultural universities; and

c) To assess the impact of CeRA on the level of research publications measured through NAAS ID and Science Citation Index.

\section{DELIVERABLES}

1. Online accessibility of all important journals and other resources related to Agriculture and Allied sciences to researchers and students of the consortium;

2. Quick access to R\&D information as available worldwide and permanent archive of the Subscribed e-databases; and

3. Improvement in the quality of scientific publications, teaching and research guidance. 


\section{ACCOMPLISHMENTS}

IP-based access to CeRA resources has been made available to NARS institutions and universities. Web-based URL (www.cera.jccc.in) is available with easy and customised interface and facilitating the online access and document delivery. More than 2900 journals are covered.

- Subscription to all relevant and important resources from American Association for Advances of Science, American Society for Microbiology, American Society for Agronomy Annual Review ,BioOneBe,Cabi, Springer, CSIRO, Elsevier, Taylor and Francis, Nature, SCI, Indian journals, Oxford, Wiley, ASA, etc. have been made available.

- Numbers of training/workshop/orientation programs have been arranged at local and national level for maximising the usage of subscribed resources.

- Researchers being assisted to access full-text of library subscribed journals (which are not available in CeRA); the Document Delivery Request System has been in place.

- CeRA maintains usage and other data for compiling the reports and further improving the system.

- Steering, monitoring cum negotiation, and working committees have been constituted and meetings are held periodically to achieve objectives of consortium.

- CeRA in collaboration with e-Granth and AALDI organised a Seminar cum User Meet on

In the fast emerging information explosion it is very difficult to access particular information without wasting time. The electronic resources give the solution and the users are attached towards electronic resources because of its greater potential in facilitating the search of required information quickly. Vast e-resources are available in agriculture and its allied disciplines, which we can access in library information centres \& provide the information to library users. In the agriculture research some of the important electronic resources like electronic journal, online database, abstracts, e-books, online catalogue, and directories have pages of the institutes' organization etc.

\section{SKUAST-K}

SKUAST-K is established on 1984 and subsequently named as Sher-e-kashmir University of Agricultural Sciences \& Technology after a great political leader Shiekh Mohd Abdullah.The main campus is situated $15 \mathrm{Km}$ from city and it is multi Campii University with six faculties. The basic men date assigned to this university are advancement in teaching, research and imparting extension education to the farmers of state. These five faculties catering the similar services in their locality.

The present study is carried at faculty of Fisheries which is located in Ganderbal Distt and is $22 \mathrm{Km}$ from city having natural water supply for fish pond and carrying research in fishery science

\section{LITERATURE REVIEW}

Bostick Sharon L (2001) argued that the buying power of the libraries for better prices has increased under the consortia mode. Lebowitz (1997) observed that, "Although many consider the library to be the heart of the university, the use of the library is often not incorporated into courses being prepared for distance delivery .... as academic institutions extend their educational offerings beyond the campus, to rural, suburban, and urban locations, they need to consider... the role that the library plays in the educational process". She recommends that librarians convince fellow educators and administrators that as they are expanding their institutions' educational offerings beyond the campus boundaries, they need to provide their 
students with access to library services, which include among others, instruction in use of resources, document delivery, and communication facility between the students and librarian.

As per the study of Singh and Tiwari (2010) all the agricultural university libraries are connected by networking system. While the under graduates are primarily using networks for communication purpose through social networking system group, the post graduate students are using for dissertations and other research assignments. Teachers are using Internet for support of their research work and preparing papers for journals. It is experienced that author and title searches are conducted on the web using Google and Google scholar. Singh et al (1996, pp.9-13) in their study on, "electronic journals on library and information science", traced out that, electronic journals clearly have potential advantages in terms of flexibility over printed journals, however, can diminish these perceptions. Ahesh and Ghosh (1998, pp.67-76) in their study on, "availability and use of indigenous database by S \& T libraries: a case study" pointed out that, science and technology libraries in Delhi are willing to buy and make use of indigenous databases compared to traditional resources.

A good amount of literature is available on the internet via open access form. In the year1992 only the five journals were freely accessible and the number increased to 1200 in the year 2004 (Falk,2004).An investigation regarding the sources of various open access journals was carried out by Kaufman-wills Group (2005) and it was found that only 248 journals were indexed in the Directory of Open Access Journals (DOAJ) from all disciplines among only $45 \%$ were in Science \& Technology, $34 \%$ in medicine, $10 \%$ in the social science and $7 \%$ in Arts \& Humanities .Lone ,Rather, and Shah (2008)revealed that there were 3756 open access journals in the DOAJ, and the top five contributing countries were the USA, Brazil UK, Spain and Germany.

\section{OBJECTIVES}

The main objective of the study is to analyse various aspects of open access journals in the field of fisheries science registrated in the directory of Open Access Journals (DOAJ).Broadly, the present study aims:

- To identify the subject coverage of journals in the field of fisheries science

- To identify the growth-rate of journals in the field of fisheries science

- To identify the publishing countries of journals in the field of Fisheries science

- To identify the leading publishers of journals in the field of fisheries science

- To know the accessibility of Archives of e-journals on Fisheries on CeRA

- To know the usefulness and applicability of Fisheries e-journals.

\section{METHODOLOGY}

In the present study the directory of the E- Journals was selected as the sources for identification in the field of fisheries science. There are eighty three (87) fisheries journals registrated in the CeRA in the April, 2018The data were collected and websites (homepages) of these journals in order to achieve the set objectives. 
Access to CeRA Consortium in SKUAST-K, Fisheries E-Journals: An Informative Study

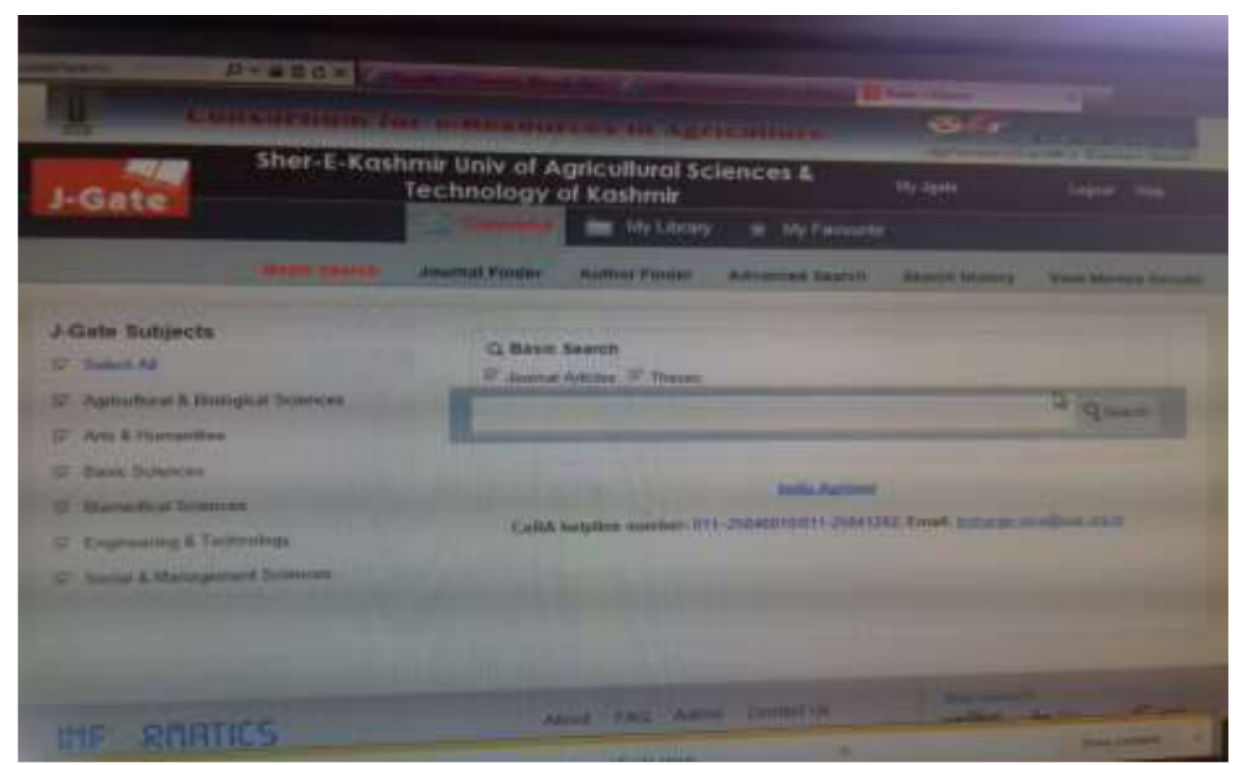

Table 1 Distribution of Subject Heading of E-Journals on Fisheries

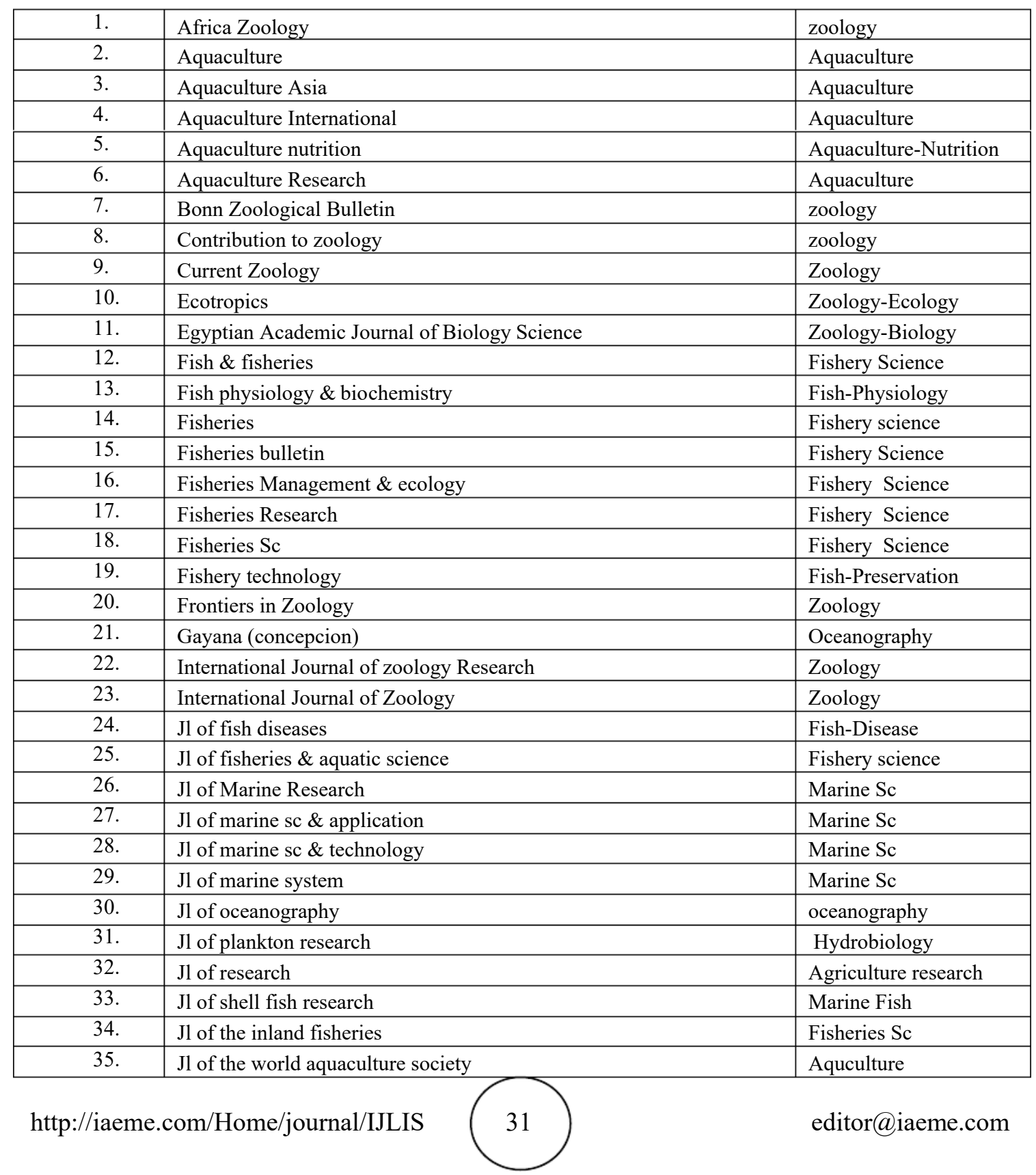


Asifa Jan and Ridwana Bach

\begin{tabular}{|c|c|c|}
\hline 36. & $\mathrm{Jl}$ of zoology & Zoology \\
\hline 37. & Journal of Fish Biology & Fishery sc \\
\hline 38. & Khurushehtra & Agriculture \\
\hline 39. & Limnology \& oceanography & limnology \\
\hline 40. & Limnology ecology \& management of inland water & Limnology \\
\hline 41. & Marine \& coastal fisheries & Marine sc \\
\hline 42. & Marine ornithology & Marine Sc \\
\hline 43. & Marine \& freshwater behaviour \& physiology & Marine Sc \\
\hline 44. & Marine \& Freshwater resources & Marine sc \\
\hline 45. & Marine biology & Marine Sc \\
\hline 46. & Marine biology research & Marine Sc \\
\hline 47. & Marine biotech & Marine Sc \\
\hline 48. & Marine biotechnology & Marine sc \\
\hline 49. & Marine chemistry & Marine sc \\
\hline 50. & Marine ecology & Marine Sc \\
\hline 51. & Marine ecology progress series & Marine Sc \\
\hline 52. & Marine environment Research & Marine Sc \\
\hline 53. & Marine fisheries review & Marine Sc \\
\hline 54. & Marine Genomics & Marine sc \\
\hline 55. & Marine Geoday & Marine sc \\
\hline 56. & Marine geode sty & Marine sc \\
\hline 57. & Marine Georesources \& Geotechnology & Marine Sc \\
\hline 58. & Marine mammals & Marine sc \\
\hline 59. & Marine Policy & Marine sc \\
\hline 60. & Marine pollution & Marine sc -pollution \\
\hline 61. & Marine pollution Bulletin & Marine sc-Pollution \\
\hline 62. & Marine resources & Marine Resources \\
\hline 63. & Marine resources economics & Marine-Resources \\
\hline 64. & Marine Science & Marine Sc \\
\hline 65. & Mollusc & Shell fish \\
\hline 66. & Nature & Life Sc \\
\hline 67. & Neotropical ichthyology & Fishery sc \\
\hline 68. & New Zealand J1 of Marine \& freshwater research & Marine-Freshwater Res \\
\hline 69. & New Zealand jl of zoology & Zoology \\
\hline 70. & North America Journal of Aquaculture & Aquaculture \\
\hline 71. & North American $\mathrm{jl}$ of fisheries management & Fishery sc \\
\hline 72. & Open Fish science Jl & Fishery sc \\
\hline 73. & Parasitic diseases & Parasitology \\
\hline 74. & Parasitology & Parasitology \\
\hline 75. & Progress in oceanography & Oceanography \\
\hline 76. & Review in aquaculture & Aquaculture \\
\hline 77. & Review in fish biology & Fishery sc \\
\hline 78. & Review in fish $\mathrm{Sc}$ & Fishery sc \\
\hline 79. & Ribarstvo Creatian Journal of fisheries & Fishery sc \\
\hline 80. & Serie Zoologica & Zoology \\
\hline 81. & Transaction of the American fisheries society & Fishery sc \\
\hline 82. & Turkish Jl of fisheries \& Aquatic Science & Fishery sc \\
\hline 83. & Turkish jl of zoology & Zoology \\
\hline 84. & Zoology & zoology \\
\hline 85. & Zoological Research & zoology \\
\hline
\end{tabular}




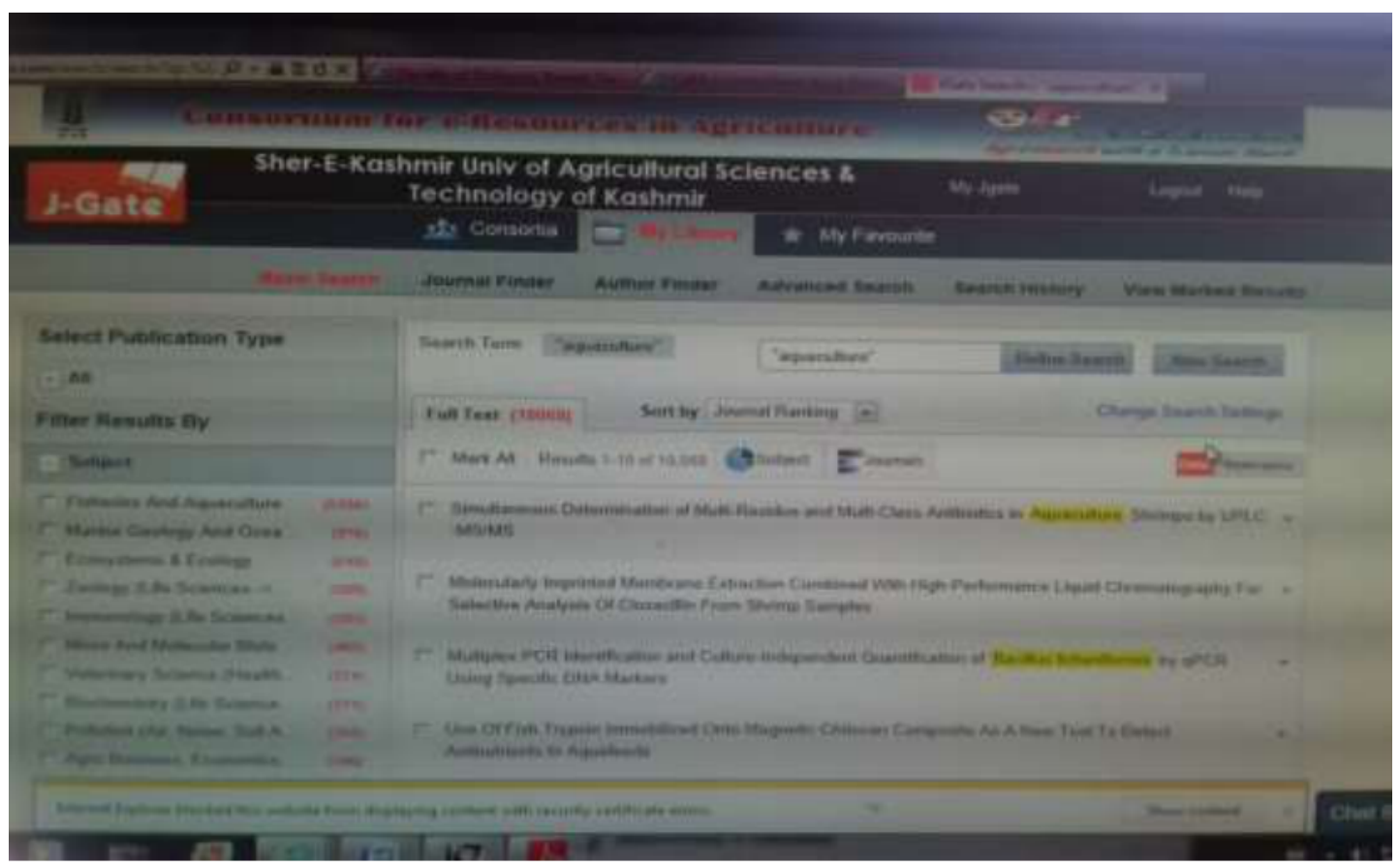

Analysis of Subject Headings of E-Journals on Zoology

\begin{tabular}{|c|l|c|c|}
\hline S NO & \multicolumn{1}{|c|}{ Subject Heading } & $\begin{array}{c}\text { No of } \\
\text { Journals }\end{array}$ & $\mathbf{\%}$ \\
\hline 1. & Agriculture-Fisheries & 2 & 2.30 \\
\hline 2. & Aquaculture-Fisheries Science & 24 & 27.59 \\
\hline 3. & Fish-Disease & 01 & 1.15 \\
\hline 4. & Fish -Nutrition & 01 & 1.15 \\
\hline 5. & Fish-Physiology & 01 & 1.15 \\
\hline 6. & Fish-Preservation & 01 & 1.15 \\
\hline 7. & Hydrobiology-Planktons & 01 & 1.15 \\
\hline 8. & Life Sc & 01 & 1.15 \\
\hline 9. & Limnology & 02 & 2.30 \\
\hline 10. & Marine Sc & 41 & 47.13 \\
\hline 11. & Marine-Pollution & 02 & 2.30 \\
\hline 12. & Marine-Resources & 02 & 2.30 \\
\hline 13. & Oceanography & 02 & 3.45 \\
\hline 14. & Parasitology & 15 & 2.30 \\
\hline 15. & Zoology & 01 & 17.24 \\
\hline 16. & Zoology-Biology & 01 & 1.15 \\
\hline 17. & Zoology -Ecology & 87 & 1.15 \\
\hline 18. & Total & 100 \\
\hline
\end{tabular}

The CeRA lists 87 journals in the field of fishery science. The maximum journals publish article on marine science $(41,47.13 \%)$ only whereas $24(27.59 \%)$ publish article on Aquaculture-Fisheries Science and 15 (17.24\%) only on Zoology. whereas few journals are related to the specialized field of the limnology, oceanography, parasitology, planktons, life science. 
Asifa Jan and Ridwana Bach

Table 2 Growth-rate of the Fisheries Journals

\begin{tabular}{|l|l|l|l|}
\hline NO & \multicolumn{1}{|c|}{ Time Peroid } & \multicolumn{1}{|c|}{ Number } & $\begin{array}{c}\text { Cumulative } \\
\text { Number }\end{array}$ \\
\hline 1. & $1964-1975$ & 06 & 06 \\
\hline 2. & $1976-85$ & 06 & 12 \\
\hline 3. & $1986-95$ & 8 & 20 \\
\hline 4. & $1996-2005$ & 25 & 45 \\
\hline 5. & $2006-2015$ & 26 & 71 \\
\hline 6. & $2016-$ & 16 & 87 \\
\hline
\end{tabular}

It is evident from the data that the e-journals are published very fast and gaining momentum every passing day. There were only 45 fisheries journal till 2005 and the number increases at a very exponential rate after every 5 years.

Table 3 Leading Publishers of the Fisheries Journals

\begin{tabular}{|c|c|c|c|}
\hline Rank & Publisher & Number & Percentage \\
\hline 1. & Elsevier & 26 & 29.87 \\
\hline 2. & Tylor \& Francis & 16 & 18.39 \\
\hline 3. & Springer & 14 & 16.09 \\
\hline 4. & John Wiley & 12 & 13.79 \\
\hline 5. & CSIRO,Iindia & 2 & 2.30 \\
\hline 6. & Inter Research & 2 & 2.30 \\
\hline 7. & $\begin{array}{l}\text { Ministry of } \\
\text { Information \& } \\
\text { Broadcasting,India }\end{array}$ & 2 & 2.30 \\
\hline 8. & $\begin{array}{l}\text { Society of Fisheries } \\
\text { Technology }\end{array}$ & 2 & 2.30 \\
\hline 9. & Cambridge & 1 & 1.15 \\
\hline 10. & $\begin{array}{l}\text { Central Fisheries } \\
\text { Research Council, } \\
\text { Turkey }\end{array}$ & 1 & 1.15 \\
\hline 11. & $\begin{array}{l}\text { Inland Fisheries } \\
\text { Association,India }\end{array}$ & 1 & 1.15 \\
\hline 12. & $\begin{array}{l}\text { Marine Biology } \\
\text { Assoication,India }\end{array}$ & 1 & 1.15 \\
\hline 13. & $\begin{array}{l}\text { National Marine } \\
\text { Fisheries }\end{array}$ & 1 & 1.15 \\
\hline 14. & Nature Publication & 1 & 1.15 \\
\hline 15. & $\begin{array}{l}\text { Oxford University } \\
\text { press }\end{array}$ & 1 & 1.15 \\
\hline 16. & Scientific Pub & 1 & 1.15 \\
\hline 17. & $\begin{array}{l}\text { Sear Foundation of } \\
\text { Marine Research }\end{array}$ & 1 & 1.15 \\
\hline 18. & $\begin{array}{l}\text { University Chicago } \\
\text { press }\end{array}$ & 1 & 1.15 \\
\hline
\end{tabular}

The maximum number of journals is contributed by Elsevier followed by the Taylor \& Francis and Springer and John Wiley publications respectively four publisher has published two each in fisheries and 10 publishers published one in the fisheries science 
Table 4 Publishing Countries of the Fisheries Journals

\begin{tabular}{|c|l|c|c|}
\hline SNO & Place of Publication & $\begin{array}{l}\text { No of e- } \\
\text { Journals }\end{array}$ & Rank \\
\hline 1. & Africa & 01 & 4 \\
\hline 2. & Australia & 01 & 4 \\
\hline 3. & China & 03 & 3 \\
\hline 4. & Croatia & 01 & 4 \\
\hline 5. & Egypt & 01 & 4 \\
\hline 6. & Europe & 01 & 4 \\
\hline 7. & Germany & 01 & 4 \\
\hline 8. & Herzegovina & 01 & 2 \\
\hline 9. & India & 04 & 4 \\
\hline 10. & Germany & 01 & 4 \\
\hline 11. & Portuguese & 01 & 1 \\
\hline 12. & United States & 71 & 4 \\
\hline
\end{tabular}

Table 4 depicts the country wise distribution of E-journals on Zoology on CeRA United States was in 1st rank due to publication of 71 e-journals followed by India with 04 publication and chine with 3 publications in fisheries science. Rest of countries publish 1 Journal each.

\section{FINDINGS}

- It is observed that united state was ist rank due to publication of 71 e-journals followed India

- English is the most common communication language to spread the knowledge in all over the world which is used by all 71 e-journals out 87 e-journals in fisheries 03 e-journals is published in Chinese language 01published in Portugues, Croatin ,Bosnian.

- It is observed that fisheries e-journals are interdisciplinary in nature. Out of 87 e-journals 39 ejournals are useful for purely for fisheries science as core subject, but fisheries journals can also be useful for marine science, Marine Resources. Limnology oceanography, ecology, agriculture \& hydrobiology and zoology research researcher scholars \& scientists

\section{CONCLUSIONS}

CeRA is comprehensive \& core all open access scientific \& scholarly Journals use an appropriates Quality control system and it will not be limited to parental language or subject area.

CeRA is IP based access has been made available to NARS institution \& university and it will not be limited to particular language or subject areas.

It is available with easy $\&$ customised interface $\&$ facilitating the online access $\&$ document delivery. Researcher being assisted to access full text of library subscribed journals. It also provides access to thesis published in India

\section{REFERENCES}

[1] Ali N( 2005). The use of electronic resources at IIT Delhi Library: a study of search behaviour. The Electronic library; 23(2): 200-203.

[2] Lihitkar Ramdas, Lihitkar Shalini R,.Waghmare,Pranati(2013).open access Zoology found on DOAJ:an analytical study, international Journal of Life Science.1(4):321-327 .

[3] Rabiya, Mustaq. And Loan, Fayaz. Ahmad.2017.open access health and Medicine Journal An informative study .webology .14 (2): 90-100.

[4] SinghB,. Tiwari B,(2010).Library networking and internet facilities in agricultural university library in India: a survey 2009.Proceeding of national conference on knowledge management in globalised era,p297 